\title{
GENERAL MANAGEMENT
}

\section{Job insecurity, job satisfaction and organisational commitment in turbulent economic times at a textile and clothing manufacturing company}

\section{Stephen TADUVANA ${ }^{1}$, Steven Kayambazinthu MSOSA ${ }^{2 *}$, Tatenda CHIKUKWA ${ }^{3}$}

\author{
${ }^{1}$ Durban University of Technology, Faculty of Management Sciences, Durban, South Africa; \\ E-mail:21143363@dut4life.ac.za \\ ${ }^{2}$ Mangosuthu University of Technology, Faculty of Management Sciences, Durban, South Africa; \\ E-mail: msosa.steven@mut.ac.za \\ ${ }^{3}$ Durban University of Technology, Faculty of Management Sciences, Durban, South Africa; \\ E-mail: tatendac@dut.ac.za \\ * Corresponding Author
}

\author{
Received: 22.11.2021 \\ Accepted: 15.12.2021 \\ Published: 02.02.2022 \\ DOI: $10.47750 / Q A S / 23.186 .04$
}

\begin{abstract}
In Zimbabwe's textile manufacturing business, job insecurity has risen dramatically over the past decade as a result of poor economic growth, retrenchments, and company closures. The purpose of this research was to assess the relationship between job insecurity, job satisfaction, and organizational commitment at a textile and clothing manufacturing company. This study adopted a quantitative and descriptive research design. A survey method was employed for all 109 permanent and contract employees. However, 102 employees returned the questionnaire representing a $93.58 \%$ participation rate. Data was analysed using descriptive and inferential statistics by means of the SPSS. The findings revealed that job insecurity and organisational commitment have a significant relationship. The findings also revealed that job insecurity had no relationship with job satisfaction. Thus, management at the selected textile and clothing manufacturing organisation are encouraged to provide salaries and benefits that are market-related.
\end{abstract}

Keywords: Job insecurity, job satisfaction, organisational commitment, manufacturing

\section{Introduction}

Job insecurity among the workforce has become more widespread in recent years as a result of fierce rivalry among employers, the global recession, and poor economic conditions, particularly in the Less Economically Developed Countries (LEDCs) which include Zimbabwe (Kang, Gold and Kim, 2012). Furthermore, job insecurity has increased because of organisational changes, restructuring, and downsizing of the workforce (Mashoue, 2011). Tshuma (2015) asserts that job insecurity in Zimbabwe is disturbingly high, with most people increasingly feeling uneasy in their positions as a result of the country's ongoing and worsening economic woes, which have resulted in large company closures and job losses. According to Mpofu (2013), Zimbabwe's apparel sector industry had 495 enterprises in 2000 , but only 206 companies have survived thus far. Since 2000, Zimbabwe's apparel industry has had negative growth, with many manufacturers shutting down. As a result, many textile industry personnel have lost their employment.

Nguwi (2015) points out that the majority of companies in Zimbabwe have laid off their employees, and many of them are not being compensated. Employees are unsure whether their prospects are improving or not as a result of these challenges. Srivastava (2013) acknowledges that organisations are confronted with the most difficult challenge of keeping the workforce both satisfied and committed. The clothing industry in Zimbabwe has seen a sharp decline in employment, from 36
000 in 2005 to 7000 in 2014. For example, in the 1990s, the selected clothing-manufacturing firm, which was founded in 1968 , employed more than 300 people, but it now employs only 109 people. Due to the difficult economic conditions in Zimbabwe, textile and garment manufacturing companies are struggling to stay afloat. This has resulted in staff shrinkage, rise in contractual employment, decreasing performance and absenteeism (Youmans, 2014).

\section{Literature review}

\subsection{Job insecurity}

Job insecurity is viewed from two perspectives: a multidimensional and a global perspective (Dachapalli and Parumasur, 2012). Job insecurity is defined as a fear or concern about the possibility of losing one's work or having one's job terminated (Pienaar, De Witte, Hellgren and Sverke, 2013). The global view approach has three components: perceptions, a sense of insecurity about the future, and skepticism about the job's long-term viability (Van Wyk and Piennar, 2008). Yousoff, Mat, and Zainol (2014) believe that job insecurity is defined as an employee's expectations of employment stability which includes not only the threat of losing one's job, but also the fear of losing the most important aspects of one's job, such as salary, advancement opportunities, status, and access to resources (Dachapalli and Parumasur, 2012). 
Reinardy (2012) argues that job insecurity is a multidimensional concept that entails the permanent loss of the job and valued job facets. The multidimensional definition of job insecurity is suitable because it focuses on the loss of valuable job qualities, the overall job, and psychological powerlessness. Another school of thought by Rogelberg (2007) suggests that insecurity can be classified as subjective or objective, cognitive or affective, and quantitative or qualitative job insecurity. Subjective job insecurity is defined by De Witte, Vander Elst, and De Cuyper (2015) as a worker's impression of the risk of losing their job. Borman and Hegde (2012) describe subjective job insecurity as the awareness of a probable risk of losing one's current employment, as well as a sense of powerlessness to maintain the required continuity in such a work scenario. Individual views of work security, which can be influenced by economic, social, organizational, and individual aspects, are at the heart of subjective job insecurity (Barling and Cooper, 2008).

Thus, the level of a perceived danger to job security and the risk that it poses to individual job elements or the entire job is measured by the threat's severity (Ritcher, 2011). Pay and benefits, promotional opportunities, and job position (salience of job components) are all determined by the job's importance (Dachapalli and Parumasur, 2012). Furthermore, the importance of job facets impacts compensation, promotion opportunities, and job position. Despite the threat being of minor severity to the affected employee, the subsequent loss of these valued aspects is somewhat job insecurity in the sense that it includes the affected individual losing his or her employment (Greenhalgh and Rosenblatt, 2010). According to Rodelberg (2007), the severity of the threat can be influenced by a range of unfavourable occurrences that have a negative impact on an individual's overall employment, such as being fired or retrenched for a short period. The importance of the entire job defines how important it is to a person, and a perceived danger to total job loss is an estimated chance of losing the job itself or the perception of losing the job. As a result, it is important to remember that adding the fear of losing a job and the fear of losing valuable job characteristics yields a weighted rate of the threat's intensity (Mashoeu, 2011).

\subsection{Job satisfaction}

Many theories and models of employee behaviour and attitudes focus on job satisfaction (Judge and Klinger, 2009). Job satisfaction, according to Azeem and Akhtar (2014), is a pleasurable positive affective state resulting from the evaluation of one's job or work experience. According to Azadeh and Ahranjani (2014), what makes a job enjoyable depends not only on the job environment but also on the demands of the individual. Job satisfaction is a complex concept that includes workers' feelings about a variety of internal and external factors. Furthermore, employee perceptions and attitudes toward their work have a significant impact on their productivity (Mahmood and Amiresmaili, 2013).

Job satisfaction involves judgments and attitudes about a variety of aspects, including work, rewards, promotion chances, supervision, job security, and relationships with co-workers (Zhang, Diaz, Tang, and Tang, 2013). Job satisfaction is also influenced by the availability of authority, status, and task clarity whereas job characteristics and job design are drivers of job satisfaction (Ozturk, Hance, and Young-Im (2014). Furthermore, Gunlu, Aksarayli, and Percin (2009) believe that there are three types of employee attitudes about job satisfaction: intrinsic, extrinsic, and generic reinforcement elements. When these are summed up, the job satisfaction construct is formed. Extrinsic factors such as company policies, administration, working conditions, and employee relations are dissatisfiers, while intrinsic factors such as achievement, recognition, the work itself, and responsibility are satisfiers (Dinoka, Perera, Khatibi, Navaratraia and China, 2014).

There are several theories explaining job satisfaction (Ciarniene, Kumpikaite and Vienazindiene, 2010). Process and content theories are the two categories in which these theories are classified. The Equity Theory, Vroom's Expectancy Theory, Job Characteristics Model, Goal-Setting Theory, and Lawler's Expectancy Model are examples of process theories that explain how wants and objectives are satisfied and accepted cognitively. The content theories, on the other hand, are concerned with understanding the individual's requirements and goals, as well as prioritizing them for job satisfaction. Well documented content theories of job satisfaction are Maslow's Hierarchy of Needs; Herzberg's Two Factor Theory; Theory $X$ and $Y$ and Achievement Theory (Saif, Nawaz, Jan and Khan, 2012). Herzberg's Two Factor Theory focuses on the outcomes of job satisfaction and job discontent. Furthermore, the theory emphasises that certain job characteristics create job satisfaction and motivation and that certain variables can also lead to job dissatisfaction (Dugguh and Dennis, 2014). The relevance of the work environment as the main factor of employee satisfaction is highlighted by Herzberg's theory (Ciarniene, Kumpikaite and Vienazindiene, 2010). The Equity Theory, according to Man, Modrak, Dima, and Pachura (2011), demonstrates how an individual sees fairness in social relationships. A person will be content if he or she believes the relationship is fair. The individual, on the other hand, will be unsatisfied if the relationship is viewed as unfair.

\subsection{Relationship between job insecurity and job satisfaction}

Job insecurity and job satisfaction have a positive relationship (Noraishah, Nasir, and Khairuddin 2012). Therefore, job insecurity is a factor of job satisfaction (Chirumbolo, 2014); and Mahmoud and Reisel, 2014). The association between job insecurity and job satisfaction is logical because employment provides employees with economic stability, social ties, and self-efficacy (Dachapalli and Parumasur, 2012). Job insecurity, according to Labuschagne, Bosman, and Buitendach (2005) and Mashoeu (2011), has a significant impact on employee attitudes toward their work and is connected to lower levels of job satisfaction.

The impact of job insecurity on job satisfaction is not just a factor of how likely it is for a person to lose their job, but also how likely it is for them to find another. This has a significant impact on job satisfaction, which is dependent on whether the employee is insecure or not, as well as whether job opportunities are scarce or plentiful (Artz and Kaya, 2014). According to Mahmoud and Reisel (2014), overtime workers develop and build emotional attachments to their employers, with job satisfaction being the most important of these attachments. It is important to highlight, however, that job insecurity may jeopardise and weaken bonds to the job and organisation.

Previous research has found that how people perceive job insecurity and how they cope with change has an impact on job satisfaction (Reinardy, 2012). A study conducted in the Gauteng Province in South Africa by Buitendach and De Witte (2005) discovered that job insecurity is linked to lower organisational commitment and job satisfaction. This is because job insecurity is a stressor that leads to bad work attitudes such as low job satisfaction and organisational commitment (De Witte, 2005). Sverke, Hellgren, and Naswall (2006), on the other hand, suggest that such negative views are unimportant because workers are individuals who interpret their circumstances differently from one another. 


\subsection{Organisational commitment}

Organisational commitment is the characteristic of an individual's recognizable proof of belonging to and inclusion in a particular organisation (Huang and Hsiao (2007). Similarly, Akoto and Akoto (2014) believe that organisational commitment is a psychological condition in which an individual feels a link with the organisation as a whole, rather than a specific task or workgroup (Lambert, Kim, Kelley and Hogan, 2013). According to Beukes and Botha (2013), there are two types of commitment: moral and attitudinal commitment. Moral commitment refers to a person's connection or allegiance to something. Srivasta (2013); Gunlu, Aksarayli and Percin (2009); and Ozturk, Hancer, and Young (2014) all point out that there are two approaches to organisational commitment, based on attitude and behaviour. Attitudinal organisational commitment is a multidimensional concept consisting of affective, continuance, and normative commitment (Cetin, Kizil and Zengin (2013). Affective commitment is based on an employee's emotional relationship to the company, whereas continuance commitment is based on the costs associated with quitting the company. Furthermore, normative commitment is an employee's perception of their desire to remain with the company (Quick and Nelson, 2013).

Organisational commitment is critical in order to build loyal teams, achieve high performance, and for organisations to successfully use employee skills to achieve organisational objectives (You, Huang, Wang, Ni-Liu, Lin and Tseng, 2013). Organisational commitment is an index for organisational effectiveness (Srivastava, 2013). Organisational commitment is crucial since it influences organisational citizenship behaviours, absenteeism, tardiness, turnover, counter-productive activities, and organisational success (Becker, Ullrich, and Dick, 2013). Low organisational commitment among employees, on the other hand, is bad for the organisation, because it is connected with diminished organisational resources and competitive edge (Morrow, 2011). Employment possibilities, work environment, personal background traits and job-related elements, interpersonal interactions within the organisation, leadership style within the organisation, and the structure of the organisation are all factors that influence organisational commitment (Babalola, 2013).

\subsection{Relationship between job insecurity and organisational commitment}

Furaker and Berglund (2014) point out that there is a substantial body of research on how job insecurity affects organisational commitment. Multiple layoffs, according to Reinardy (2010), have a negative impact on employee dedication to the company. Employees who are uncertain and uneasy about their positions are less likely to feel committed to the organisation (Lee and Peccei, 2006). Furthermore, according to Buitendach and Laba (2005), job insecurity jeopardizes the fundamentals of attachment, such as commitment, satisfaction, and trust. Employees who believe their jobs are insecure are more likely to retreat and deviate at work, as well as have a low level of commitment to the organisation (Caballer, Sora, and Maria, 2010).

According to Peene (2009), the higher the amount of job insecurity, the less devoted employees are to the company and the more likely they are to leave. Past research, studies on the relationship between job insecurity and employee commitment to the organisation have generally suggested a moderate negative influence between the two variables. De Cuyper, Notelaers and De Witte (2009) found that amongst permanent workers, job insecurity has a negative association or relationship with organisational commitment. Thus, Individuals holding permanent, temporary and fixed-term contracts react differently to job insecurity. Therefore, this study aimed to investigate the relationship between job insecurity, job satisfaction and organisational commitment. Specifically, the following were the objectives of this study:

- To determine the relationship between job insecurity on job satisfaction;

- To ascertain the relationship between job insecurity and organisational commitment; and

- To evaluate the relationship between job satisfaction and organisational commitment.

\section{Methodology}

\subsection{Research design}

A research design is a framework that keeps the research together and allows the researcher to respond to the research questions more effectively (Neuman, 2014). The various types of research design are exploratory, descriptive, explanatory research, and experimental research. This study adopted a descriptive research design. Descriptive research examines events in their natural state. It is used to find out about the characteristics of a problem, such as a community, a group, or a person (Akhtar (2014). In addition to being descriptive, a quantitative research method was used. Quantitative research elucidates phenomena by collecting numerical data and analyzing it using scientifically grounded procedures (Muijs, 2011).

\subsection{Target population and sampling}

The target population for this study was 109 employees from a selected garment manufacturing company in Zimbabwe. The target population's list was received from the human resource department of the chosen company in Zimbabwe's garment manufacturing business. Out of a population of 109 permanent and contract employees, 102 participated in the study. As mentioned above, the target population was too small to warrant the selection of a sample, therefore the research study adopted a survey method that included all the 109 employees.

\subsection{Data collection}

A closed-ended structured questionnaire was used to collect primary data from all the respondents that were used in this study. The questionnaire was designed using a Likert scale and participants were requested to gauge their feelings by responding to whether they agree or disagree with a statement. Thus, out of the 109 questionnaires that were distributed, 102 questionnaires were returned representing a $93.58 \%$ response rate. Secondary data was collected from internet sources, journal publications and newspapers.

\subsection{Data analysis}

Data collected from the questionnaires was captured in an excel sheet and exported for further analysis. The data was later analysed using the latest version of the Statistical Package for Social Sciences (SPSS). Descriptive and inferential statistics were used to analyse the data. In terms of reliability of the data, job insecurity registered a Cronbach alpha coefficient score of 0.799 , organisational commitment $(0.637)$ and job satisfaction (0.790). The overall reliability score for this study was 0.620 , which is above the acceptable threshold. According to Hajjar (2018), a Cronbach alpha or reliability score above 0.5 is acceptable. Table 1 shows the reliability statistics of this study. 


\section{GENERAL MANAGEMENT}

\begin{tabular}{|l|l|}
\hline Factor & Cronbach's Alpha \\
\hline Job Insecurity & 0.799 \\
\hline Organisational Commitment & 0.637 \\
\hline Job Satisfaction & 0.790 \\
\hline Overall & 0.620 \\
\hline
\end{tabular}

Table 1: Reliability Statistics

\section{Results}

\subsection{Demographic data}

Table 2 shows the demographic profile of the respondents who participated in this study. The results show that the majority of the respondents used in this study were males who accounted for 52 per cent followed by women (48\%). With respect to age, the majority of the respondents were in the age category between 21 and 30 years (35.3\%) followed by the age category between 31 and 40 years (33.3\%), above 51 years accounted for 12.8 per cent, less than 20 years $(10.8 \%)$ and the age category between 41 and 50 years accounted for $7.8 \%$. With regard to the length of service, the majority of the respondents had served between 1 and 10 years (79.4\%) followed by those that had served between 11 and 20 years $(11.8 \%)$, above 30 years ( $4.9 \%)$ and 21 and 30 years accounted for 3.9 per cent. In terms of the type of contract, the majority of respondents were working under a fixed contract $(59.2 \%)$ followed by permanent employees (40.8\%).

\begin{tabular}{|l|l|}
\hline Gender & $48 \%$ \\
\hline Female & $52 \%$ \\
\hline Male & \\
\hline Age & $10.8 \%$ \\
\hline Less than 20 years & $35.3 \%$ \\
\hline $21-30$ years & $33.3 \%$ \\
\hline $31-40$ years & $7.8 \%$ \\
\hline $41-50$ years & $12.8 \%$ \\
\hline $51+$ years & \multicolumn{2}{|l|}{} \\
\hline Length of service & $79.4 \%$ \\
\hline $1-10$ years & $11.8 \%$ \\
\hline $11-20$ years & $3.9 \%$ \\
\hline $21-30$ years & $4.9 \%$ \\
\hline $30+$ years & \\
\hline Type of contract & $59.2 \%$ \\
\hline Contract (Fixed contract) & $40.8 \%$ \\
\hline Permanent &
\end{tabular}

Table 2: Frequency distribution of demographic data

\subsection{Inferential statistics}

\subsubsection{Job insecurity and job satisfaction}

Table 3 reveals that both the Pearson's Chi-Square test result $(p>0.05)$ and the Spearman's Rank Order Correlation
Co-efficient ( $r s<0.7)$ produced a non-significant result. The Pearson's Chi-Square value of 25.881 is less than the $x 2$ cutoff value of 26.296, whilst the Spearman's Rank Order Correlation Co-efficient of 0.543 is less than the rs cut-off value of 0.7 . The test statistics show that there is no significant relationship between job insecurity and job satisfaction.

\begin{tabular}{|l|l|l|l|}
\hline & Value & df & Asymp. Sig. (2-sided) \\
\hline Pearson Chi-square & 25.881 & 16 & 0.081 \\
\hline Likelihood ratio & 22.812 & 16 & 0.074 \\
\hline Linear-by-Linear Association & 2.912 & 1 & 0.065 \\
\hline X2 rank order & 26.296 & & \\
\hline $\begin{array}{l}\text { Spearman`s } \\
\text { Correlation co-efficient }\end{array}$ & 0.543 & & \\
\hline Number of Valid Cases & 102 & & \\
\hline
\end{tabular}

Table 3: The relationship between job insecurity and job satisfaction $(n=102)$

*Pearson Chi-Square $=25.881, d f=16$, Significant $p>0.05$, Spearman $(r s)=0.543$, Cut-off parameter: Spearman Significance ( $r$ s $>0.7$ )

\subsubsection{Job insecurity and organisational commitment}

Table 4 reveals that the Pearson's Chi-Square test result ( $p$
$<0.05)$ is significant. There is a significant correlation between job insecurity and organisational commitment. The Spearman's Rank Order Correlation Co-efficient ( $r s>0.7$ ) also supports a strong correlation between job insecurity and organisational commitment. 


\section{GENERAL MANAGEMENT}

\begin{tabular}{|l|l|l|l|}
\hline & Value & df & Asymp. Sig. (2-sided) \\
\hline Pearson Chi-Square & 38.912 & 8 & 0.049 \\
\hline Likelihood Ratio & 11.912 & 8 & 0.084 \\
\hline Linear-by-Linear Association & 3.114 & 1 & 0.761 \\
\hline X2 & 26.296 & & \\
\hline $\begin{array}{l}\text { Spearman`s rank order Correlation co- } \\
\text { efficient }\end{array}$ & 0.791 & & \\
\hline Number of Valid Cases & 102 & & \\
\hline
\end{tabular}

Table 4: The relationship between job insecurity and organisational commitment

Pearson Chi-Square $=38.912, d f=8$, Significant $p<0.05$; Spearman $(r s)=0.791$, Cut-off parameter: Spearman Significance $(r s>$ $0.7)$.

\subsubsection{Job satisfaction and organisational commitment}

With respect to Table 5, the Pearson Chi-Square value $(p<$
0.05) and Spearman's rank order correlation coefficient (rs > $0.7)$ are highly significant. Therefore, the hypothesis is accepted. This result reflects that there is a significant relationship between job satisfaction and organisational commitment.

\begin{tabular}{|l|l|l|l|}
\hline & Value & df & Asymp. Sig. (2-sided) \\
\hline Pearson Chi-Square & 45.712 & 8 & 0.0001 \\
\hline Likelihood Ratio & 39.871 & 8 & 0.009 \\
\hline Linear-by-Linear Association & 6.911 & 1 & 0.082 \\
\hline X2 & 26.296 & & \\
\hline $\begin{array}{l}\text { Spearman`s rank order Correlation co- } \\
\text { efficient }\end{array}$ & 0.814 & & \\
\hline Number of Valid Cases & 102 & & \\
\hline
\end{tabular}

Table 5: Relationship between job satisfaction and organisational commitment

*Pearson Chi-Square $=45.712, d f=8$, Significant $p<0.05$, Spearman $(r s)=0.814$, Cut-off parameter: Spearman Significance (rs > 0.7)

\section{Discussion}

The aim of this study was to analyse the relationship between job satisfaction, job insecurity and organisational commitment. The first analysis sought to evaluate the relationship between job insecurity and job satisfaction. Despite the notion that numerous studies have shown that job insecurity has a significant relationship with job satisfaction, this study found no significant link between job insecurity and job satisfaction. Therefore, the findings of this study are not consistent with the study by Cheung, Wu and Chi (2019) among casino employees. In this study, there was a negative relationship between job insecurity and job satisfaction. Similarly, the findings of this study do not agree with Setya and Saroyini (2020), who investigated the effect of job insecurity on job satisfaction among employees of Indo China Service Company. Job insecurity was found to be negatively related to job satisfaction in the study. The contradiction in the findings may be because of other factors that are unique to the employees, industry and the country that are critical to job satisfaction and that job insecurity may not be a very important factor.

The study further sought to evaluate the relationship between job insecurity and organisational commitment. The findings showed that there is a significant correlation between job insecurity and organisational commitment. The findings of this study concur with another study at Andalas University Hospital (Elvianita and Muchtar, 2020). Thus, to be efficient and effective, institutions must ensure that their employees are dedicated and that their working environment is less stressful.
Employees who are stressed out and unsure about their future job security are less likely to be committed to their company (Burke, 2017).

Lastly, the study evaluated the relationship between job satisfaction and organisational commitment. This result reflects that there is a significant relationship between job satisfaction and organisational commitment. The findings are in line with those of Candelario, Tindowen, Mendezabal, Quilang (2020), who conducted research among government employees on the relationship between job satisfaction and organisational commitment and found that job satisfaction and organisational commitment have a significant relationship. Furthermore, Gopinath, Kalpana, Ramamoorthy, Bhawiya Roopaa and Karthikeyan (2021) investigated the relationship between job satisfaction and organisational commitment among academic leaders in Tamil Nadu Universities. The findings showed that job satisfaction and organisational commitment have a significant relationship.

\section{Conclusion}

This study evaluated the relationship between job insecurity, job satisfaction and organisational commitment. Based on the findings, management is encouraged to provide members of staff with benefits such as salaries that are competitive and comparable to other organisations on the market. This will assist the organisation to reduce employee turnover and ultimately achieve job satisfaction. In addition, there is a need for management to regularly review their current offerings through employee satisfaction surveys. Thus, to 
create a conducive work environment, managers must ensure that employee communication channels are enhanced. Managers need to cultivate a good working relationship and create mutual trust with their subordinates. This will enable the organisation to create a pool of loyal and committed employees geared at achieving company objectives. This study has contributed to the literature on job satisfaction, organisational commitment and job insecurity from the developing world where organisations struggle to perform optimally and subsequently fail to reward their employees because of the prevailing economic conditions. Future research should focus on a qualitative understanding of employees' perception of job satisfaction, job security and other variables within the human resources and labour framework.

\section{References}

[1] Akhtar, I. 2014. Research design. Research in Social Science: Interdisciplinary Perspectives. New Delhi: Jamia Millia Islamia

[2] Akoto, E. O., \& Akoto, E. V. (2014). The configural approach to organisational commitment: An application in Ghana. SA Journal of Industrial Psychology, 40(2). doi:10.4102/sajip.v40i2.1207

[3] Artz, B., \& Kaya, I. (2014). The impact of job security on job satisfaction in economic contractions versus expansions. Applied Economics, 46(24), 2873-2890. doi:10.1080/00036846.2014.914148

[4] Azeem, M.S. and Akhtar, N. (2014). Job satisfaction and organisational commitment among public sector employees in Saudi Arabia. International Journal of Business and Social Sciences, 5(7):127-133.

[5] Babalola, S.S. (2013). The impact of commitment and job insecurity on openness to organisational change: the case of Nigerian civil aviation industry. African Journal of Business Management, 7(3):206-212.

[6] Becker, T. E., Ullrich, J., \& van Dick, R. (2013). Within-person variation in affective commitment to teams: Where it comes from and why it matters. Human Resource Management Review, 23(2), 131-147. doi:10.1016/j.hrmr.2012.07.006

[7] Bernston, E., Naswall, K. and Sverke, M. (2010). The moderating role of employability in the association between job insecurity and exit, voice, loyalty and neglect. Organisational Psychology Review, 1(1):1-17.

[8] Beukes, I., \& Botha, E. (2013). Organisational commitment, work engagement and meaning of work of nursing staff in hospitals. SA Journal of Industrial Psychology, 39(2). doi:10.4102/sajip.v39i2.1144

[9] Borman, W.G. and Hedge, W. J. (2012). The handbook of work and aging. New York: Oxford University Press.

[10] Bosman, J., Buitendach, J. H., \& Laba, K. (2005). Job insecurity, burnout and organisational commitment among employees of a financial institution in Gauteng. SA Journal of Industrial Psychology, 31(4). doi:10.4102/sajip.v31i4.210

[11] Burke, W. W. (2017). Organization change: Theory and practice. Washington: Sage Publications.

[12] SORA, B., CABAlLER, A., \& PEIRÓ, J. M. (2010). The consequences of job insecurity for employees: The moderator role of job dependence. International Labour Review, 149(1), 59-72. doi:10.1111/j.1564-913x.2010.00075.x

[13] Candelario, L., Tindowen, D., Mendezabal, M.J. and Quilang, P., (2020). Organizational commitment and job satisfaction among government employees. International Journal of Innovation, Creativity, and Change.

[14] Çetin, A. T., Kızıl, C., \& Zengin, H. İ. (2013). Impact of Mentoring on Organizational Commitment and Job Satisfaction of Accounting-Finance Academicians Employed in Turkey. EMAJ: Emerging Markets Journal, 3(2), 1-28. doi:10.5195/emaj.2013.40

[15] Chirumbolo, A. (2014). The Impact of Job Insecurity on
Counterproductive Work Behaviors: The Moderating Role of Honesty-Humility Personality Trait. The Journal of $\begin{array}{lll}\text { Psychology, 149(6), 554-569. } & \text {. }\end{array}$ doi:10.1080/00223980.2014.916250

[16] Ciarniene, R., Kumpikaite, V. and Vienazindiene, M. (2010). Expectations and job satisfaction. A theoretical and empirical approach. Business and Management, 1(1): 978-984.

[17] Cooper, C.L. and Barling, J. (2008). The sage handbook of organisational behaviour. London: Sage Publications.

[18] Paul Dachapalli, L.-A., \& Parumasur, S. B. (2012). Employee susceptibility to experiencing job insecurity. South African Journal of Economic and Management Sciences, 15(1), 3143. doi:10.4102/sajems.v15i1.125

[19] De Cuyper, N., Notelaers, G., \& De Witte, H. (2009). Job insecurity and employability in fixed-term contractors, agency workers, and permanent workers: Associations with job satisfaction and affective organizational commitment. Journal of Occupational Health Psychology, 14(2), 193-205. doi:10.1037/a0014603

[20] De Witte, H. (2005). Job insecurity: Review of the international literature on definitions, prevalence, antecedents and consequences. SA Journal of Industrial Psychology, 31(4). doi:10.4102/sajip.v31i4.200

[21] De Witte, H., Vander Elst, T., \& De Cuyper, N. (2015). Job Insecurity, Health and Well-Being. Sustainable Working Lives, 109-128. doi:10.1007/978-94-017-9798-6_7

[22] Dugguh, S., \& Dennis, A. (2014). Job satisfaction theories: Traceability to employee performance in organizations. IOSR Journal of Business and Management, 16(5), 11-18. doi: $10.9790 / 487 x-16511118$

[23] Elvianita, U., \& Muchtar, B. (2020). The Effect of Job Insecurity, Job Satisfaction and Organizational Commitment on Turnover Intention at Andalas University Hospital. Proceedings of the 5th Padang International Conference On Economics Education, Economics, Business and Management, Accounting and Entrepreneurship (PICEEBA-5 2020). doi:10.2991/aebmr.k.201126.086

[24] Furåker, B., \& Berglund, T. (2015). Inseguridad laboral y compromiso organizativo. Revista Internacional de Organizaciones, 0(13), 163. doi:10.17345/rio13.163-186

[25] Gopinath, R., Kalpana, R., Ramamoorthy, R., Roopaa, S.B. and Karthikeyan, S., (2021). Job Satisfaction, Organisational Commitment and influence on Work Performance of Academic Leaders in Tamil Nadu Universities through Structural Equation Modeling. Design Engineering, 7: 5604-5618.

[26] Greenhalgh, L., \& Rosenblatt, Z. (2010). Evolution of Research on Job Insecurity. International Studies of Management \& Organization, 40(1), 6-19. doi:10.2753/imo0020-8825400101

[27] Gunlu, E., Aksarayli, M., \& Şahin Perçin, N. (2010). Job satisfaction and organizational commitment of hotel managers in Turkey.

[28] Hajjar, S.T., (2018). Statistical analysis: Internal-consistency reliability and construct validity. International Journal of Quantitative and Qualitative Research Methods, 6(1): 7-38.

[29] Huang, T.-C., \& Hsiao, W.-J. (2007). THE CAUSAL RELATIONSHIP BETWEEN JOB SATISFACTION AND ORGANIZATIONAL COMMITMENT. Social Behavior and Personality: An International Journal, 35(9), 1265-1276. doi:10.2224/sbp.2007.35.9.1265

[30] Judge, A.T. and Klinger, R. (2009). Handbook of principles of organisational behaviour. London: John Wiley and sons.

[31] Kang, D., Gold, J., \& Kim, D. (2012). Responses to job insecurity. Career Development International, 17(4), 314-332. doi:10.1108/13620431211255815

[32] Labuschagne, M., Bosman, J. and Buitendach, J.H. (2005). Job insecurity, job satisfaction and work locus of control of employees in a government organisation. South African Journal of Human Resources Management, 3(2):26-35.

[33] Lambert, E. G., Kim, B., Kelley, T., \& Hogan, N. L. (2013). The association of affective and continuance commitment with correctional staff life satisfaction. The Social Science Journal, 


\section{GENERAL MANAGEMENT}

50(2), 195-203. doi:10.1016/j.soscij.2013.02.001

[34] Mahmood, M. and Amiresmaili, M. (2013). Determining job satisfaction of nurses working in hospitals. Iranian Journal of Nursing and Midwifery Research, 18(5):343-348.

[35] Mahmoud, AB, Reisel, WD (2014) Relating patient satisfaction to nurses' job satisfaction, job security, and obedience OCBs. International Journal of Pharmaceutical and Healthcare Marketing, 8(1): 47-61.

[36] Man, M., Modrak, V., Dima, I.C. and Pachura, P. (2011). A theoretical approach to the job satisfaction. Polish Journal of Management Studies, 4(1):7-15.

[37] Morrow, P. C. (2011). Managing organizational commitment: Insights from longitudinal research. Journal of Vocational Behavior, 79(1), 18-35. doi:10.1016/j.jvb.2010.12.008

[38] Moshoeu, A.N. (2011).Job insecurity, organisational commitment and work engagement amongst staff in a tertiary institution. Unpublished Master's Thesis.

[39] Department of Industrial and organisational psychology. College of Economics and Management Sciences. Pretoria. University Press.

[40] Mpofu, T. (2013). Challenges faced by the clothing sector in Zimbabwe. IOSR Journal of Business and Management, 13(5), 83-84. doi:10.9790/487x-1358384

[41] Muijs, D. (2011). Doing Quantitative Research in Education with SPSS. doi:10.4135/9781849203241

[42] Mullins, L.J. (2010). Management and organisational behaviour. 9th Edition. London: Pearson.

[43] Neuman, W. L. (2014). Social Research: Qualitative and Quantitative Approaches, Edinburgh, Pearson Education Limited.

[44] Nguwi, M. (2015). Employee confidence drops again. Online. Available from: http.www.financialgazzete.co.zw./eyeeconfidence-drops-again-2/. Date accessed: 22 June 2015.

[45] Ozturk, A. B., Hancer, M., \& Im, J. Y. (2014). Job Characteristics, Job Satisfaction, and Organizational Commitment for Hotel Workers in Turkey. Journal of Hospitality Marketing \& Management, 23(3), 294-313. doi:10.1080/19368623.2013.796866

[46] Peene, N. (2009). Insecure times: job insecurity and its consequences on organisational commitment, occupational commitment as a moderating variable. Warandelaan: Tilburg University

[47] Perera, G.D.N., Khatibi, A., Navaratima, N. and China, K. (2014). Job satisfaction and job performance among factory employees in apparel sector. Asian Journal of Management Sciences and Education, 3(1):96-104.
[48] Pertiwi, N.S. and Piartrini, P.S., (2020). The Effect of Job Insecurity on Job Satisfaction and Intention to Quit, Case Employee of Indo China Service Company. American Journal of Humanities and Social Sciences Research, 4(6), pp.18-22.

[49] Quick, J.C. and Nelson, D.L. (2013). Principles of organisational behaviour realities and challenges. 8th Edition. London: Sothern- Western Cengage Learning.

[50] Reinardy, S. (2012). Job Security, Satisfaction Influence Work Commitment. Newspaper Research Journal, 33(1), 54-70. doi:10.1177/073953291203300105

[51] Ritcher, A. (2011). Job insecurity and its consequences. Unpublished thesis. Department of Psychology. Faculty of Humanities. Stockholm University: Sweden. US-AB Stockholm.

[52] Rodelberg, S.G. (2007). Encyclopedia of industrial and organisational psychology. London: Sage Publications.

[53] Saif, K.S., Nawaz, A., Jan, F.A. and Khan, I.M. (2002). Synthesising the theories of job satisfaction across the cultural/attitudinal dimensions. Inter disciplinary Journal of Contemporary Research in Business, 3(9):1382-1396.

[54] Srivastava, S. (2013). Job Satisfaction and Organizational Commitment Relationship: Effect of Personality Variables. Vision: The Journal of Business Perspective, 17(2), 159-167. doi:10.1177/0972262912483529

[55] Sverke, M., Hellgren, J. and Naswall, K. (2006). Job insecurity a literature review. South African Journal of Psychology, 30(1): 2-23.

[56] Tshuma, M. (2015). Job insecurity worries zim workers. Online. Available on http://www.financialgazette.co.zw/job-insecurityworries-zim-workers/. Date accessed: 22 June 2016.

[57] Van Wyk, M. and Piennar, J. (2008). Towards a research agenda for job insecurity in South Africa. Southern African Business Review, 12(2):49-86

[58] You, C., Huang, C., Wang, H., Ni-Liu,K., Lin, C. and Tseng, J. (2013). The relationship between corporate social responsibility, job satisfaction and organisational commitment. International Journal of Organisational Innovation, 5(4):65-77.

[59] Youmans, J. (2014). Clothing industry eyes $100 \%$ growth by 2020. Online. Available from: http. www.herald.co.zw/clothing-industry-eyes-100pc-growthby2020/. Date accessed: 5 November 2015.

[60] Zheng, X., Diaz, I., Tang, N., \& Tang, K. (2014). Job insecurity and job satisfaction. Career Development International, 19(4) 426-446. doi:10.1108/cdi-10-2013-0121 